Article

\title{
Rare Earth Elements and Other Critical Metals in Deep Seabed Mineral Deposits: Composition and Implications for Resource Potential
}

\author{
Sang-Joon Pak*, Inah Seo (D), Kyeong-Yong Lee and Kiseong Hyeong \\ Korea Institute of Ocean Science \& Technology, Busan 49111, Korea; inahseo@kiost.ac.kr (I.S.); \\ kylee@kiost.ac.kr (K.-Y.L.); kshyeong@kiost.ac.kr (K.H.) \\ * Correspondence: electrum@kiost.ac.kr; Tel.: +82-51-664-3467
}

Received: 27 November 2018; Accepted: 17 December 2018; Published: 21 December 2018

check for updates

\begin{abstract}
The critical metal contents of four types of seabed mineral resources, including a deep-sea sediment deposit, are evaluated as potential rare earth element (REE) resources. The deep-sea resources have relatively low total rare earth oxide (TREO) contents, a narrow range of TREO grades $(0.049-0.185 \%)$, and show characteristics that are consistent with those of land-based ion adsorption REE deposits. The relative REO distributions of the deep-seabed resources are also consistent with those of ion adsorption REE deposits on land. REEs that are not part of a crystal lattice of host minerals within deep-sea mineral deposits are favorable for mining, as there is no requirement for crushing and/or pulverizing during ore processing. Furthermore, low concentrations of Th and $\mathrm{U}$ reduce the risk of adverse environmental impacts. Despite the low TREO grades of the deep-seabed mineral deposits, a significant TREO yield from polymetallic nodules and REE-bearing deep-sea sediments from the Korean tenements has been estimated (1 Mt and $8 \mathrm{Mt}$, respectively). Compared with land-based REE deposits, deep-sea mineral deposits can be considered as low-grade mineral deposits with a large tonnage. The REEs and critical metals from deep-sea mineral deposits are important by-products and co-products of the main commodities (e.g., Co and Ni), and may increase the economic feasibility of their extraction.
\end{abstract}

Keywords: seabed mineral resource; deep-sea sediment; total rare earth oxides; critical metal; relative REO distribution; low-grade and large tonnage deposit

\section{Introduction}

The term "critical metal" refers to staple metals that are essential to advanced manufacturing, green technologies, and other growing industries [1,2]. To define critical metals, several assessments have adapted and have come to assorted decisions about the most at-risk resources, but an agreement has been made around a key group of metals such as rare earth elements, transition metals, and platinum group metals. With increasing technological advances, the demand for these critical metals has increased, raising concerns for resource sustainability. To rapidly resolve the imbalance of critical metal supply and demand, increased recycling and the substitution of critical metals by different materials have been proposed, but these approaches have been unsuccessful to date. The exploitation of seabed mineral resources such as polymetallic nodules, ferromanganese crusts, seafloor massive sulfide (SMS) deposits, and rare earth element-bearing deep-sea sediments have also been identified as possible critical metal sources [3-8].

Since an initial 1983 survey of the manganese nodules in the northeast Pacific Ocean, the Korea Institute of Ocean Science and Technology (KIOST) has actively explored deep-sea mineral resources in international waters and in the exclusive economic zones (EEZs) of various nations (Figure 1). 
The surveyed deep-sea mineral deposits include polymetallic nodules, ferromanganese crust, SMS, and deep-sea sediment, and are potential rare earth element (REE) resources (Table 1). Traditionally, $\mathrm{Co}, \mathrm{Ni}$, and $\mathrm{Mn}$ have been the target metals in nodules and crusts, with less focus on rare earth metals. The majority of REE studies have focused on the origin and genetic environment of ore deposits (e.g., [9-12] and references therein). Only a few studies have investigated the potential of classical deep-sea mineral deposits as critical metal sources, despite the discovery of seabed mineral deposits almost 50 years ago [3,4,13-16]. Critical metals were recently identified as potential seabed resource commodities; however, the extent of critical metal exploitation from seabed deposits remains unclear, because of limited data on resource estimation.

This paper discusses the critical metal contents of three conventional seabed mineral resources and a deep-sea sediment resource that is currently being explored by KIOST, and re-evaluates these deposits as potential REE resources. This study examines the resource potential of critical metals of conventional seafloor mineral deposits in Korean tenements and provides a comparison with land-based rare earth metal deposits. The future implications of, and factors relevant to, the critical metal exploitation of seabed mineral deposits are also discussed.

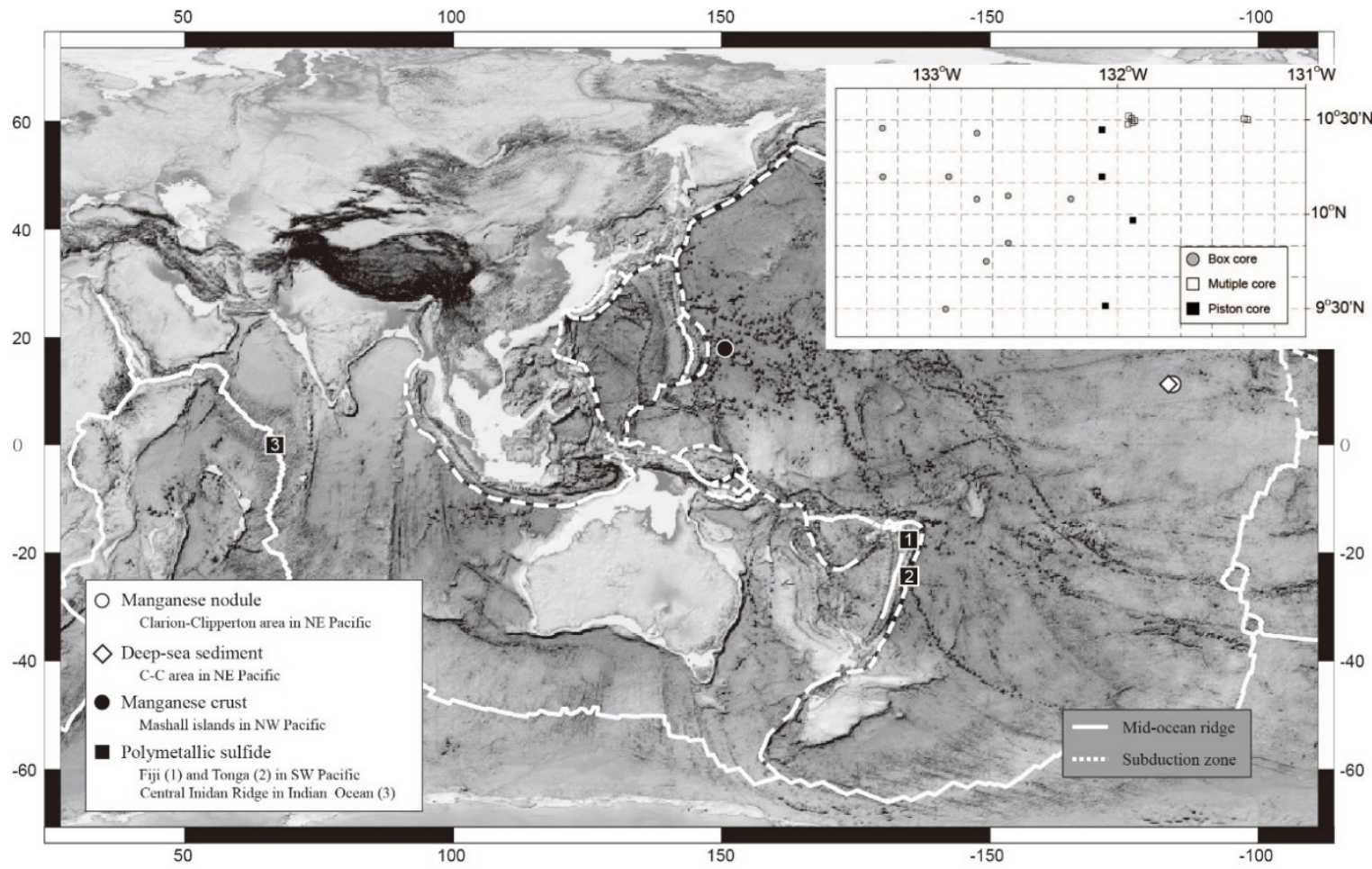

Figure 1. Global topographic map showing the locations of seabed mineral deposits surveyed by the Korea Institute of Ocean Science and Technology (KIOST). The inset panel shows the sampling sites of deep-sea sediment. 
Table 1. Features of the seabed mineral deposits surveyed by KIOST ${ }^{1}$.

\begin{tabular}{|c|c|c|c|c|c|}
\hline Type of Resource & & Polymetallic Nodule & Ferromanganese Crust & Deep-Sea Sediment & Seafloor Massive Sulfides \\
\hline \multirow{4}{*}{$\begin{array}{c}\text { Location and } \\
\text { development status }\end{array}$} & Area & Northeast Pacific Ocean & West central Pacific Ocean & Northeast Pacific Ocean & Southwest Pacific and Indian Ocean \\
\hline & Water depth & $4000-6000 \mathrm{~m}$ & $1000-2000 \mathrm{~m}$ & $4000-6000 \mathrm{~m}$ & $400-3000 \mathrm{~m}$ \\
\hline & $\begin{array}{l}\text { Relationship to high } \\
\text { sea or EEZ }\end{array}$ & High sea & High sea & High sea & $\begin{array}{l}\text { Tongan and Fijian exclusive economic } \\
\text { zone (EEZ), high sea (Indian Ocean) }\end{array}$ \\
\hline & Tenement & Yes (from ISA ${ }^{2}$ ) & Applying to ISA in 2016 & - & Yes (from Tonga, Fiji, and ISA) \\
\hline \multirow{7}{*}{ Geological features } & Geological setting & $\begin{array}{l}\text { Oceanic intraplate } \\
\text { (deep-sea plain) }\end{array}$ & $\begin{array}{l}\text { Oceanic intraplate (volcanic } \\
\text { chain, seamount) }\end{array}$ & $\begin{array}{l}\text { Oceanic intraplate } \\
\text { (deep-sea plain) }\end{array}$ & $\begin{array}{l}\text { Subduction and mid-ocean ridge } \\
\text { (volcanic chain, seamount) }\end{array}$ \\
\hline & Ore body & Nodule & Crustification & $\begin{array}{l}\text { Unconsolidated } \\
\text { sediments }\end{array}$ & Chimneys and mounds \\
\hline & Major minerals & Fe-Mn oxides & Fe-Mn oxides & Ca phosphate & Polymetallic sulfides \\
\hline & Target metals & $\mathrm{Ni}, \mathrm{Co}, \mathrm{Cu}, \mathrm{Mn}$ & $\mathrm{Co}, \mathrm{Ni}, \mathrm{Pt}$ & Rare earth elements & $\mathrm{Cu}, \mathrm{Zn}, \mathrm{Au}, \mathrm{Ag}$ \\
\hline & Genesis & Hydrogenetic, diagenetic & Hydrogenetic & Hydrogenetic, diagenetic & Hydrothermal fluid \\
\hline & Scale of deposit & $>100 \mathrm{~km}$ & $\sim 10 \mathrm{~km}$ & $>100 \mathrm{~km}$ & $\sim 1 \mathrm{~km}$ \\
\hline & Amount of resource & 188 million tons ${ }^{3}$ & Not estimated yet & 16,500 million tons ${ }^{3}$ & Not estimated yet \\
\hline
\end{tabular}

${ }^{1} \mathrm{KIOST}=$ Korea Institute of Ocean Science and Technology, ${ }^{2}$ ISA = International Seabed Authority, ${ }^{3}$ ore tonnage, see the text for reference. 


\section{Materials and Methods}

\subsection{Samples and Analysis}

Polymetallic nodules were sampled from five localities in the Korean tenement at the Clarion-Clipperton Zone (CCZ). The manganese nodules studied here were recovered by the R/V Onnuri of KIOST in 1996 and 1997. On the basis of discrimination diagrams by Bau et al. [17], nodules from the two sites in the northern part of the tenement plot in the field were hydrogenetic nodules (Figure S1), whereas the nodules in the south were digenetic [18]. The major element (e.g., Fe, Mn, and $\mathrm{Cu}$ ) and REE concentrations of 378 and 88 samples, respectively, were analyzed (Table 2). The analyzed nodules exhibited a layered growth structure, but chemical compositions were measured from bulk analyses of the entire nodule.

Ferromanganese crusts were sampled from seven seamounts near the Marshall Islands in the northwestern Pacific Ocean. Manganese crusts were recovered by the R/V Onnuri in 1999, 2001, and 2015. Manganese crusts from the sampling region plot were in the field of hydrogenetic crust (Figure S1). The majority of the sampled crusts comprise four to five layers that can be distinguished by differences in color, texture, and mineral assemblage. The lowermost layers (layers four and/or five) are characterized by carbonate fluorapatite (CFA) and low contents of critical metals. The near-surface layers are characterized by predominantly Fe-rich vernadite and hydroxides, and high contents of rare earth metals. A total of 292 individual layers were analyzed. The composition of each layer is presented as the average value of all of the analyses of that layer.

Recently, deep-sea sediments have been suggested as a possible source of rare earth metals [4]. The deep-sea sediments that were analyzed in this study were sampled from the southern part of the tenements by multiple corers (MC), box corers (BC), and piston corers (PC) with the R/V Onnuri in 1996 and 2013. The sampling sites of MC, PC, and BC were in the eastern, central, and western part of the area, respectively (Figure 1). Seven samples (eight to $30 \mathrm{~cm}$ in length) were collected by MC, and 10 samples (23-50 cm in length) were recovered by BC. Most of the samples were cut into one to $30-\mathrm{cm}$ lengths for analysis. Four cores (up to $350 \mathrm{~cm}$ in length) were recovered by PC. Some of the BC and PC samples can be subdivided into two to three units based on color, water content, and texture. The uppermost unit (Unit 1) is brown in color (10YR5/3 or 10YR4/4), $10 \mathrm{~cm}$ thick, homogeneous in texture, and has a high water content. The next layer (Unit II) is brown-yellow in color (10YR6/4-6/6) and $>20 \mathrm{~cm}$ in thickness. The basal layer (Unit III) is dark brown (10YR4/3-3/3) and has a high content of transition metals.

Seafloor massive sulfides were sampled mainly from hydrothermal chimneys and mounds in the Tongan and Fijian EEZs in the southeast Pacific Ocean. Seafloor hydrothermal sulfides in the Tongan EEZs were recovered by the German flagship R/V Sonne in 2010 and 2012. Sulfides from Fijian EEZ were collected by the R/V Onnuri in 2006. In general, the SMS exhibited Zn-Cu mineralization (Table 1). Most of the chimneys and mounds were concentrically layered and showed a transition in the type of mineralization from the inner to outermost part of the conduit in the order of Cu-bearing sulfides, Zn-bearing sulfides, and barite and/or gypsum. A total of 260 analyses were performed on the chimneys and mounds. The compositions of the individual analyses from each domain were averaged.

The major element contents were measured with a SPECTRAA-20 flame atomic absorption spectrophotometer (AAS) at KIOST, Busan, Korea. Trace element and REE concentrations were measured by inductively coupled plasma-mass spectrometry (ICP-MS, VG Elemental) and inductively coupled plasma optical emission spectrometer (ICP-OES, PerkinElmer Optima 2000 DV), also at KIOST. 
Table 2. Representative chemical compositions of polymetallic nodules, ferromanganese crusts, and seafloor massive sulfides within Korean exploration areas.

\begin{tabular}{|c|c|c|c|c|c|c|c|c|c|c|c|c|c|c|c|c|c|c|c|}
\hline \multicolumn{3}{|c|}{ Type of Resource } & \multicolumn{4}{|c|}{ Polymetallic Nodule } & \multicolumn{4}{|c|}{ Ferromanganese Crust } & \multicolumn{4}{|c|}{ Deep-Sea Sediment } & \multicolumn{4}{|c|}{ Seafloor Massive Sulfides } & \multirow{2}{*}{$\begin{array}{l}\text { Average Composition of } \\
\text { the Continental Crust * }\end{array}$} \\
\hline Group/Elemen & & Unit & Mean & Min & Max & $\mathbf{N}$ & Mean & Min & Max & $\mathbf{N}$ & Mean & Min & Max & $\mathbf{N}$ & Mean & Min & Max & $\mathbf{N}$ & \\
\hline \multirow{4}{*}{$\begin{array}{l}\text { Ferrous/non-ferrous } \\
\text { base metal }\end{array}$} & $\mathrm{Fe}$ & \multirow{4}{*}{$\%$} & 5.49 & 2.80 & 13.16 & 378 & 14.95 & 4.48 & 22.7 & 396 & - & - & - & - & 11.51 & 28 & 63.5 & 246 & 7.06 \\
\hline & $\mathrm{Cu}$ & & 0.93 & 0.22 & 1.65 & 378 & 0.11 & 0.01 & 0.34 & 396 & 0.02 & 0.02 & 0.02 & 229 & 1.37 & 0.0 & 17.9 & 260 & 0.008 \\
\hline & $\mathrm{Pb}$ & & 0.09 & 0.0 & 0.11 & 88 & 0.008 & 0.0 & 0.144 & 396 & 0.0 & 0.0 & 0.0 & 229 & 4.39 & 0.0 & 63.0 & 260 & 0.001 \\
\hline & $\mathrm{Zn}$ & & 0.0 & 0.0 & 0.0 & 378 & 0.004 & 0.0 & 0.065 & 396 & 0.01 & 0.01 & 0.01 & 229 & 6.48 & 0.0 & 56.7 & 247 & 0.008 \\
\hline \multirow{30}{*}{ Rare metals } & $\mathrm{Li}$ & \multirow{3}{*}{$\mathrm{mg} / \mathrm{kg}$} & - & - & - & - & 4.55 & 0.0 & 51.48 & 234 & - & - & - & - & 2.50 & 0.03 & 111 & 252 & 13.0 \\
\hline & $\mathrm{Be}$ & & 2.9 & 2.0 & 5.0 & 10 & 4.13 & 1.230 & 10.30 & 235 & - & - & - & - & 0.16 & 0.05 & 1.0 & 252 & 1.5 \\
\hline & B & & - & - & - & - & 151.5 & 64.46 & 437.52 & 235 & - & - & - & - & - & - & - & - & 10.0 \\
\hline & $\mathrm{Ti}$ & $\%$ & - & - & - & - & 0.84 & 0.23 & 1.54 & 396 & 0.29 & 0.04 & 0.42 & 229 & 0.05 & 0.0 & 0.68 & 253 & 0.53 \\
\hline & $\mathrm{V}$ & & 571.8 & 137.0 & 850.0 & 88 & 580.0 & 222.9 & 891.0 & 396 & 113.3 & 35.0 & 202.0 & 229 & 49.1 & 1.0 & 713.0 & 248 & 230.0 \\
\hline & $\mathrm{Cr}$ & $\mathrm{mg} / \mathrm{kg}$ & 11.3 & 7.0 & 114.0 & 88 & 58.15 & 0.1 & 194.6 & 396 & 45.7 & 0.0 & 84.0 & 229 & 25.1 & 1.0 & 140.0 & 87 & 185.0 \\
\hline & $\mathrm{Mn}$ & & 23.86 & 10.13 & 33.31 & 378 & 22.19 & 8.29 & 34.51 & 396 & - & - & - & - & 0.25 & 0.0 & 9.84 & 261 & 0.14 \\
\hline & $\mathrm{Co}$ & $\%$ & 0.21 & 0.11 & 0.48 & 378 & 0.22 & 0.0 & 0.94 & 396 & 0.01 & 0.0 & 0.06 & 229 & 0.0 & 0.0 & 0.0 & 255 & 0.003 \\
\hline & $\mathrm{Ni}$ & & 1.08 & 0.31 & 1.57 & 378 & 0.2 & 0.0 & 0.99 & 396 & 0.03 & 0.01 & 0.09 & 229 & 0.0 & 0.0 & 0.01 & 261 & 0.011 \\
\hline & $\mathrm{Ga}$ & \multirow{4}{*}{$\mathrm{mg} / \mathrm{kg}$} & 41.2 & 17.0 & 72.0 & 10 & 273.1 & 5.0 & 830.4 & 213 & 21.9 & 5.0 & 36.0 & 229 & 39.4 & 0.05 & 350.0 & 261 & 18.0 \\
\hline & $\mathrm{Ge}$ & & 0.7 & 0.5 & 1.0 & 10 & 9.7 & 2.37 & 38.0 & 202 & - & - & - & - & 3.8 & 0.05 & 98.9 & 261 & 1.6 \\
\hline & $\mathrm{Se}$ & & - & - & - & - & 15.7 & 0.0 & 27.7 & 175 & - & - & - & - & 10.8 & 0.05 & 59.6 & 254 & 0.05 \\
\hline & $\mathrm{Rb}$ & & 12.5 & 7.0 & 16.0 & 10 & 10.9 & 0.0 & 83.0 & 336 & - & - & - & - & 0.95 & 0.1 & 11.3 & 252 & 32.0 \\
\hline & $\mathrm{Sr}$ & $\%$ & 0.07 & 0.02 & 0.13 & 88 & 0.42 & 0.05 & 5.6 & 396 & 0.02 & 0.02 & 0.02 & 229 & 0.02 & 0.0 & 0.1 & 254 & 0.026 \\
\hline & $\mathrm{Zr}$ & \multirow{7}{*}{$\mathrm{mg} / \mathrm{kg}$} & 174.3 & 41.0 & 463.0 & 87 & 1043.0 & 79.2 & 9833.8 & 396 & 147.8 & 30.0 & 228.0 & 229 & 10.2 & 0.5 & 87.0 & 253 & 100.0 \\
\hline & $\mathrm{Nb}$ & & 21.2 & 7.0 & 43.0 & 10 & 54.6 & 15.3 & 89.3 & 235 & 10.4 & 0.0 & 21.1 & 229 & 0.16 & 0.05 & 1.6 & 252 & 11.0 \\
\hline & Mo & & 585.7 & 100.0 & 940.0 & 88 & 466.9 & 24.0 & 894.0 & 396 & - & - & - & - & 84.8 & 0.5 & 1110 & 261 & 1.0 \\
\hline & In & & 0.14 & 0.1 & 0.3 & 10 & - & - & - & - & - & - & - & - & 1.31 & 0.05 & 41.2 & 254 & 0.05 \\
\hline & $\mathrm{Sb}$ & & 31.3 & 18.2 & 44.5 & 10 & 33.05 & 3.4 & 67.0 & 396 & 2.11 & 0.0 & 6.1 & 229 & 457.5 & 0.51 & 5280 & 244 & 0.2 \\
\hline & $\mathrm{Te}$ & & - & - & - & - & 57.31 & 3.66 & 155.96 & 235 & - & - & - & - & 0.22 & 0.05 & 1.8 & 245 & 0.005 \\
\hline & Cs & & 0.91 & 0.25 & 1.7 & 10 & 0.78 & 0.0 & 3.13 & 175 & - & - & - & - & 0.46 & 0.03 & 2.05 & 254 & 1.0 \\
\hline & $\mathrm{Ba}$ & $\%$ & 0.26 & 0.12 & 0.83 & 88 & 117.08 & 0.0 & 4273 & 396 & - & - & - & - & 12.37 & 0.0 & 48.8 & 243 & 0.025 \\
\hline & Hf & \multirow{8}{*}{$\mathrm{mg} / \mathrm{kg}$} & 5.44 & 3.0 & 9.9 & 10 & 8.8 & 1.0 & 17.0 & 232 & - & - & - & - & 0.29 & 0.05 & 7.1 & 254 & 3.0 \\
\hline & $\mathrm{Ta}$ & & 0.16 & 0.05 & 0.2 & 10 & 1.34 & 0.0 & 10.2 & 175 & - & - & - & - & 0.09 & 0.05 & 7.1 & 247 & 1.0 \\
\hline & W & & 43.7 & 25.0 & 59.0 & 10 & 79.94 & 14.9 & 184. & 235 & 4.2 & 0.0 & 19.4 & 229 & 19.76 & 2.4 & 38.94 & 18 & 1.0 \\
\hline & $\mathrm{Re}$ & & - & - & - & - & 0.01 & 0.0 & 0.08 & 175 & - & - & - & - & 0.0 & 0.0 & 0.09 & 252 & - \\
\hline & $\mathrm{Tl}$ & & 79.12 & 60.0 & 98.4 & 10 & 147.79 & 6.0 & 265.11 & 213 & - & - & - & - & 38.27 & 0.14 & 461.0 & 254 & 0.36 \\
\hline & $\mathrm{Bi}$ & & 11.67 & 4.4 & 25.5 & 10 & 34.2 & 0.0 & 56.5 & 20 & - & - & - & - & 0.06 & 0.01 & 3.32 & 254 & 0.06 \\
\hline & Th & & 23.65 & 6.0 & 67.0 & 88 & 9.69 & 0.59 & 38.0 & 361 & 7.8 & 0.0 & 15.0 & 229 & 0.12 & 0.05 & 3.5 & 245 & 10.7 \\
\hline & U & & 4.5 & 1.0 & 9.0 & 88 & 10.47 & 3.76 & 15.82 & 251 & 1.38 & 0.2 & 2.6 & 229 & 1.78 & 0.05 & 31.2 & 245 & 2.8 \\
\hline
\end{tabular}


Table 2. Cont.

\begin{tabular}{|c|c|c|c|c|c|c|c|c|c|c|c|c|c|c|c|c|c|c|c|}
\hline \multicolumn{3}{|c|}{ Type of Resource } & \multicolumn{4}{|c|}{ Polymetallic Nodule } & \multicolumn{4}{|c|}{ Ferromanganese Crust } & \multicolumn{4}{|c|}{ Deep-Sea Sediment } & \multicolumn{4}{|c|}{ Seafloor Massive Sulfides } & \multirow{2}{*}{$\begin{array}{l}\text { Average Composition o } \\
\text { the Continental Crust * }\end{array}$} \\
\hline Group/Elemen & & Unit & Mean & Min & Max & $\mathbf{N}$ & Mean & Min & Max & $\mathbf{N}$ & Mean & Min & Max & $\mathbf{N}$ & Mean & Min & Max & $\mathbf{N}$ & \\
\hline \multirow{17}{*}{ Rare earth elements } & Sc & \multirow{17}{*}{$\mathrm{mg} / \mathrm{kg}$} & 8.9 & 7.0 & 11.0 & 10 & 9.26 & 1.4 & 30.1 & 396 & 27.39 & 5.0 & 47.0 & 229 & 4.39 & 0.09 & 47.79 & 194 & 30.0 \\
\hline & Y & & 86.03 & 15.0 & 133.0 & 88 & 168.19 & 0.0 & 734.02 & 369 & 94.37 & 8.0 & 250.0 & 291 & 2.78 & 0.05 & 42.1 & 247 & 20.0 \\
\hline & $\mathrm{La}$ & & 127.6 & 38.0 & 248.0 & 88 & 216.37 & 0.0 & 487.6 & 384 & 60.97 & 16.0 & 166.0 & 291 & 1.28 & 0.05 & 22.7 & 252 & 16.0 \\
\hline & $\mathrm{Ce}$ & & 553.42 & 178.0 & 1592 & 88 & 792.03 & 0.0 & 1750 & 384 & 70.63 & 7.0 & 364.0 & 291 & 2.4 & 0.05 & 38.1 & 252 & 33.0 \\
\hline & $\operatorname{Pr}$ & & 36.82 & 9.0 & 66.0 & 88 & 38.59 & 0.0 & 214.3 & 384 & 19.18 & 5.0 & 47.7 & 291 & 0.31 & 0.05 & 3.9 & 250 & 3.9 \\
\hline & $\mathrm{Nd}$ & & 148.15 & 37.0 & 266.0 & 88 & 165.56 & 0.0 & 479.8 & 384 & 79.62 & 21.0 & 201.0 & 291 & 1.2 & 0.05 & 13.4 & 251 & 16.0 \\
\hline & $\mathrm{Sm}$ & & 34.93 & 9.0 & 61.0 & 88 & 33.68 & 0.0 & 129.4 & 384 & 17.76 & 5.0 & 45.0 & 291 & 0.34 & 0.05 & 3.8 & 249 & 3.5 \\
\hline & $\mathrm{Eu}$ & & 8.51 & 2.0 & 15.0 & 88 & 13.05 & 0.0 & 64.1 & 384 & 5.28 & 1.7 & 28.1 & 291 & 0.32 & 0.03 & 12.2 & 251 & 1.1 \\
\hline & $\mathrm{Gd}$ & & 35.58 & 9.0 & 66.0 & 88 & 41.68 & 0.0 & 116.5 & 384 & 19.23 & 6.0 & 52.0 & 291 & 0.42 & 0.05 & 5.5 & 250 & 3.3 \\
\hline & $\mathrm{Tb}$ & & 5.48 & 1.0 & 9.0 & 88 & 5.99 & 0.0 & 56.6 & 384 & 3.02 & 0.3 & 8.16 & 291 & 0.46 & 0.05 & 6.7 & 249 & 0.6 \\
\hline & Dy & & 28.78 & 7.0 & 50.0 & 88 & 35.26 & 0.0 & 91.6 & 384 & 16.88 & 4.3 & 42.8 & 291 & 0.1 & 0.01 & 0.9 & 247 & 3.7 \\
\hline & Ho & & 5.44 & 1.0 & 9.0 & 88 & 7.47 & 0.0 & 26.4 & 384 & 3.32 & 0.3 & 9.12 & 291 & 0.13 & 0.01 & 1.5 & 247 & 0.78 \\
\hline & $\mathrm{Er}$ & & 14.93 & 3.0 & 25.0 & 88 & 22.04 & 0.0 & 53.73 & 384 & 9.13 & 2.3 & 23.1 & 291 & 0.32 & 0.02 & 4.5 & 249 & 2.2 \\
\hline & $\mathrm{Tm}$ & & 2.01 & 1.48 & 4.0 & 88 & 3.25 & 0.0 & 23.6 & 384 & 1.26 & 0.2 & 3.4 & 291 & 0.08 & 0.0 & 0.7 & 247 & 0.32 \\
\hline & $\mathrm{Yb}$ & & 13.96 & 3.0 & 23.00 & 88 & 20.68 & 0.0 & 45.02 & 384 & 8.06 & 2.3 & 20.0 & 291 & 0.3 & 0.05 & 4.3 & 249 & 2.2 \\
\hline & $\mathrm{Lu}$ & & 2.0 & 0.0 & 4.0 & 88 & 3.18 & 0.0 & 16.5 & 384 & 1.22 & 0.3 & 3.3 & 291 & 0.08 & 0.01 & 0.7 & 249 & 0.3 \\
\hline & TREE & & 1017.6 & & & & 1398.8 & & & & 315.6 & & & & 7.7 & & & & \\
\hline \multirow{2}{*}{ Precious metals } & $\mathrm{Au}$ & \multirow{2}{*}{$\mathrm{mg} / \mathrm{kg}$} & - & - & - & - & 0.12 & 0.0 & 2.17 & 126 & - & - & - & - & 8.73 & 0.01 & 60.9 & 235 & 0.003 \\
\hline & $\mathrm{Ag}$ & & 0.46 & 0.25 & 1.2 & 10 & 0.64 & 0.0 & 2.33 & 136 & - & - & - & - & 202.68 & 0.08 & 1860 & 246 & 0.08 \\
\hline \multirow{6}{*}{$\begin{array}{l}\text { Platinum group } \\
\text { elements }\end{array}$} & Ir & \multirow{6}{*}{$\mu \mathrm{g} / \mathrm{kg}$} & - & - & - & - & 26.6 & 0.46 & 186.85 & 147 & - & - & - & - & - & - & - & - & 0.2 \\
\hline & Os & & - & - & - & - & 3.0 & 2.0 & 4.0 & 17 & - & - & - & - & - & - & - & - & 1.0 \\
\hline & $\mathrm{Pd}$ & & - & - & - & - & 272.52 & 2.0 & 1242.6 & 192 & - & - & - & - & - & - & - & - & 1.9 \\
\hline & $\mathrm{Pt}$ & & - & - & - & - & 607.22 & 52.46 & 2441.3 & 192 & - & - & - & - & - & - & - & - & 2.4 \\
\hline & $\mathrm{Rh}$ & & - & - & - & - & 88.7 & 12.0 & 172.6 & 192 & - & - & - & - & - & - & - & - & 0.5 \\
\hline & $\mathrm{Ru}$ & & - & - & - & - & 18.83 & 3.47 & 33.41 & 192 & - & - & - & - & - & - & - & - & 1.0 \\
\hline
\end{tabular}

Data for polymetallic nodules are compiled from KORDI (the former name of KIOST) reports [19,20]. Data for ferromanganese crusts are from this study, and KORDI reports [21,22]. Data for deep-sea sediment are compiled from this study and a KORDI report [10]. The metal contents of seafloor massive sulfides are from this study and a KORDI report [23]. *Average compositions are from two compilations, except for the platinum group elements (PGEs) [24,25]. The crustal compositions of the PGEs are from Hein et al. [26]. Abbreviations: Min, minimum; Max, maximum; N, number of analyses. 


\subsection{Classification of Critical Metals and Rare Earth Oxides}

The criteria for classifying critical metals differs slightly between different countries, depending on their technical capability and economic situation. In this study, we classified 47 elements as critical metals, including 30 key metals, 15 rare-earth elements (lanthanoids), and Sc and Y. Table 2 lists these elements by metal group and grade for the seabed resources currently surveyed by Korea. We also consider precious metals (i.e., $\mathrm{Au}$ and $\mathrm{Ag}$ ) and platinum group elements (PGEs; i.e., $\mathrm{Ru}, \mathrm{Rh}, \mathrm{Pd}$, Os, Ir, and $\mathrm{Pt}$ ) with the critical metals because, together, these metals increase the value of deep-sea mineral resources. Palladium and Pt are classified as both critical metals and PGEs, but are considered solely as PGEs in this study.

A number of factors, including the ore and total rare earth oxide (TREO) tonnage, and ore grade, can be used to assess the feasibility of REE deposits. The REE ore grades of land-based REE deposits are typically reported in terms of rare earth oxide (REO) percentage, because REEs are commonly traded in REO units. The REE contents of the seabed samples that are analyzed in this study are converted to oxides to facilitate a comparison with the ore grades of land-based REE deposits. The relative REO distribution (RRD) and basket price can also be used to evaluate REE deposits. RRD is expressed as the REO/TREO percentage. The basket price is the potential price without considering the ore grade or total recovery rate. The short-term to medium-term supply of heavy rare earth elements (HREEs) such as dysprosium, neodymium, terbium, europium, and yttrium is diminishing, which is creating challenges for clean energy technology [27-29]. The increasing demand for clean energy technologies, such as those implemented by the permanent magnet and phosphor industries, means that REEs such as neodymium, praseodymium, and dysprosium (magnets), and europium and yttrium (phosphors) are key elements in growing markets, leading to high prices [6]. Light REEs (e.g., La and Ce) are used primarily as abrasive materials and are cheaper than HREEs. REEs in ores are generally mixed together. REE-bearing ore bodies with a given total REO percentage may vary in the proportion of HREEs, which affects the value of the ore. Therefore, we categorized the REEs into three groups that reflect the HREE content of the ore. The first group comprises $\mathrm{Sm}_{2} \mathrm{O}_{3}, \mathrm{Er}_{2} \mathrm{O}_{3}, \mathrm{Gd}_{2} \mathrm{O}_{3}, \mathrm{~Tb}_{2} \mathrm{O}_{3}$, and $\mathrm{Y}_{2} \mathrm{O}_{3}$ (the SEGTY group), which are vital for phosphor manufacturing and have the highest basket price. The second group comprises $\mathrm{Nd}_{2} \mathrm{O}_{3}, \mathrm{Pr}_{2} \mathrm{O}_{3}$, and $\mathrm{Dy}_{2} \mathrm{O}_{3}$ (the NPD group), which are essential for permanent magnet production. The third group comprises $\mathrm{La}_{2} \mathrm{O}_{3}$ and $\mathrm{Ce}_{2} \mathrm{O}_{3}$ (the $\mathrm{LC}$ group), which are used as abrasives and have a low basket price. In this study, RRD refers to the total of LC, NPD, and SEGTY divided by the TREO content (i.e., the summation of $\mathrm{La}_{2} \mathrm{O}_{3}, \mathrm{Ce}_{2} \mathrm{O}_{3}, \mathrm{Nd}_{2} \mathrm{O}_{3}, \mathrm{Pr}_{2} \mathrm{O}_{3}, \mathrm{Dy}_{2} \mathrm{O}_{3}$, $\mathrm{Sm}_{2} \mathrm{O}_{3}, \mathrm{Er}_{2} \mathrm{O}_{3}, \mathrm{Gd}_{2} \mathrm{O}_{3}, \mathrm{Y}_{2} \mathrm{O}_{3}$, and $\mathrm{Tb}_{2} \mathrm{O}_{3}$ ).

\section{Results}

\subsection{Polymetallic Nodules}

The concentrations of critical metals $\mathrm{Mo}, \mathrm{Tl}, \mathrm{Bi}, \mathrm{Mn}, \mathrm{Sb}, \mathrm{Ni}$, and $\mathrm{Co}$ in the nodules are $\sim 100 \times$ more enriched than in the average continental crust (Figure 2A). In this section, the average continental crust (ACC) is adopted in order to illustrate the resource potential of critical metals. Manganese, $\mathrm{Ni}$, and Co have been key commodities since the 1970s, owing to the market situation at that time. Nodules from the central Pacific Ocean and Indian Ocean [15] are enriched in Pd (average $3668 \mu \mathrm{g} / \mathrm{kg}$ ) by a factor of 1900 relative to the average continental crust. Their $\mathrm{Pt}$ and $\mathrm{Rh}$ concentrations range between $120-930 \mu \mathrm{g} / \mathrm{kg}$ and $11-39 \mu \mathrm{g} / \mathrm{kg}$, respectively (50-400 $\times$ and $20-80 \times$ average continental crust, respectively; Figure 2A). Silver is only slightly enriched relative to the average continental crust, with average contents of $0.5 \mathrm{mg} / \mathrm{kg}$ and $\sim 1.9 \mathrm{mg} / \mathrm{kg}$ in nodules from the Korean tenement and the Indian Ocean, respectively [15]. 

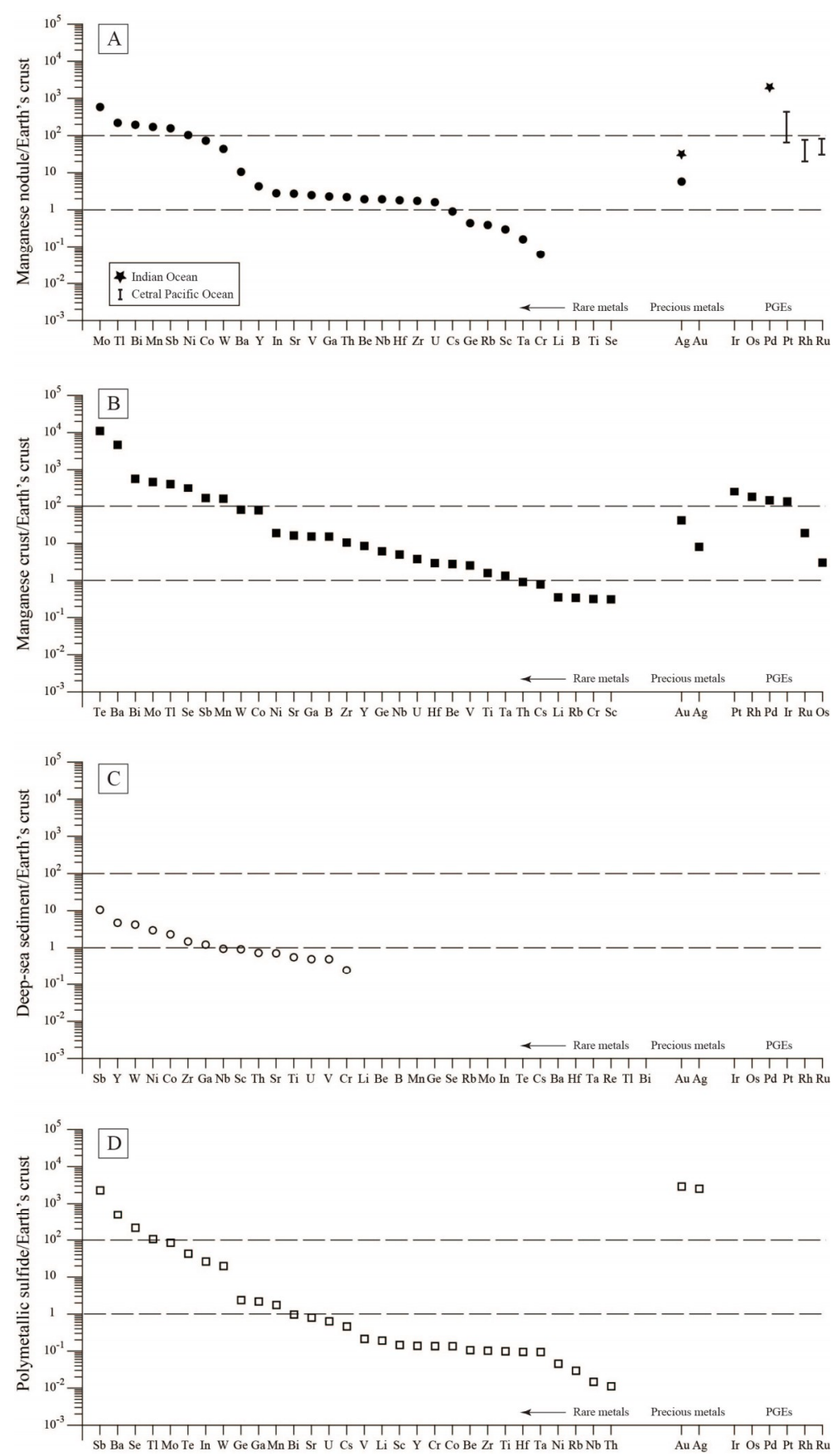

Figure 2. Average concentrations of rare and precious metals normalized by the composition of average continental crust for (A) polymetallic nodules, (B) ferromanganese crusts, (C) deep-sea sediments, and (D) seafloor massive sulfides within the Korean tenements. Abbreviations: ACC, composition of average continental crust; PGEs, platinum group elements.

The TREO contents of the polymetallic nodules range between $0.037-0.302 \%$, with an average value of $0.13 \%$ (Table 3). Nodules from the two northern sites have slightly higher TREO contents (average $0.133 \%$ ) than those from the three southern areas (average $0.104 \%$, [28]). The nodule RRD comprises $63.6 \%$ LC, $19.9 \%$ NPD, and 16.5\% SEGTY (Figure 3). The largest component (LC) has the lowest value (1.2 USD $/ \mathrm{kg}$ ), whereas NPD is the most expensive (13.0 USD $/ \mathrm{kg}$; Table 4). The SEGTY component has the highest basket price, meaning it has a slightly higher overall value (3.7 USD $/ \mathrm{kg})$ than LC, despite its lower abundance (Table 4). 
Table 3. Rare earth oxide contents (\%) of polymetallic nodules, ferromanganese crusts, deep-sea sediments, and seafloor massive sulfides.

\begin{tabular}{|c|c|c|c|c|c|c|c|c|c|c|c|c|c|c|c|c|}
\hline \multirow{2}{*}{ Resource Type (\%) } & \multicolumn{4}{|c|}{ Polymetallic Nodule } & \multicolumn{4}{|c|}{ Ferromanganese Crust } & \multicolumn{4}{|c|}{ Deep-Sea Sediment } & \multicolumn{4}{|c|}{ Seafloor Massive Sulfides } \\
\hline & Mean & Min & Max & $\mathbf{N}$ & Mean & Min & Max & $\mathbf{N}$ & Mean & Min & Max & $\mathbf{N}$ & Mean & Min & Max & $\mathbf{N}$ \\
\hline $\mathrm{La}_{2} \mathrm{O}_{3}$ & 0.015 & 0.004 & 0.029 & 88 & 0.025 & 0.002 & 0.057 & 384 & 0.007 & 0.002 & 0.019 & 291 & 0.000 & 0.000 & 0.003 & 259 \\
\hline $\mathrm{Ce}_{2} \mathrm{O}_{3}$ & 0.065 & 0.021 & 0.186 & 88 & 0.093 & 0.003 & 0.205 & 384 & 0.008 & 0.001 & 0.043 & 291 & 0.000 & 0.000 & 0.004 & 259 \\
\hline $\mathrm{Pr}_{2} \mathrm{O}_{3}$ & 0.004 & 0.001 & 0.008 & 88 & 0.005 & 0.000 & 0.025 & 384 & 0.002 & 0.001 & 0.006 & 291 & 0.000 & 0.000 & 0.000 & 257 \\
\hline $\mathrm{Nd}_{2} \mathrm{O}_{3}$ & 0.017 & 0.004 & 0.031 & 88 & 0.019 & 0.002 & 0.056 & 384 & 0.009 & 0.002 & 0.023 & 291 & 0.000 & 0.000 & 0.002 & 258 \\
\hline $\mathrm{Sm}_{2} \mathrm{O}_{3}$ & 0.004 & 0.001 & 0.007 & 88 & 0.004 & 0.001 & 0.015 & 384 & 0.002 & 0.001 & 0.005 & 291 & 0.000 & 0.000 & 0.000 & 256 \\
\hline $\mathrm{Eu}_{2} \mathrm{O}_{3}$ & 0.001 & 0.000 & 0.002 & 88 & 0.002 & 0.000 & 0.007 & 384 & 0.001 & 0.000 & 0.003 & 291 & 0.000 & 0.000 & 0.001 & 258 \\
\hline $\mathrm{Gd}_{2} \mathrm{O}_{3}$ & 0.004 & 0.001 & 0.008 & 88 & 0.005 & 0.001 & 0.013 & 384 & 0.002 & 0.001 & 0.006 & 291 & 0.000 & 0.000 & 0.001 & 257 \\
\hline $\mathrm{Tb}_{2} \mathrm{O}_{3}$ & 0.001 & 0.000 & 0.001 & 88 & 0.001 & 0.000 & 0.007 & 384 & 0.000 & 0.000 & 0.001 & 291 & 0.000 & 0.000 & 0.001 & 256 \\
\hline $\mathrm{Dy}_{2} \mathrm{O}_{3}$ & 0.003 & 0.001 & 0.006 & 88 & 0.004 & 0.000 & 0.011 & 384 & 0.002 & 0.000 & 0.005 & 291 & 0.000 & 0.000 & 0.000 & 254 \\
\hline $\mathrm{Ho}_{2} \mathrm{O}_{3}$ & 0.001 & 0.000 & 0.001 & 88 & 0.001 & 0.000 & 0.003 & 384 & 0.000 & 0.000 & 0.001 & 291 & 0.000 & 0.000 & 0.000 & 254 \\
\hline $\mathrm{Er}_{2} \mathrm{O}_{3}$ & 0.002 & 0.000 & 0.003 & 88 & 0.003 & 0.000 & 0.006 & 384 & 0.001 & 0.000 & 0.003 & 291 & 0.000 & 0.000 & 0.001 & 256 \\
\hline $\mathrm{Tm}_{2} \mathrm{O}_{3}$ & 0.000 & 0.000 & 0.000 & 88 & 0.000 & 0.000 & 0.003 & 384 & 0.000 & 0.000 & 0.000 & 291 & 0.000 & 0.000 & 0.000 & 254 \\
\hline $\mathrm{Yb}_{2} \mathrm{O}_{3}$ & 0.002 & 0.000 & 0.003 & 88 & 0.002 & 0.000 & 0.005 & 384 & 0.001 & 0.000 & 0.002 & 291 & 0.000 & 0.000 & 0.000 & 256 \\
\hline $\mathrm{Lu}_{2} \mathrm{O}_{3}$ & 0.000 & 0.000 & 0.000 & 88 & 0.000 & 0.000 & 0.002 & 384 & 0.000 & 0.000 & 0.000 & 291 & 0.000 & 0.000 & 0.000 & 256 \\
\hline $\mathrm{Y}_{2} \mathrm{O}_{3}$ & 0.011 & 0.002 & 0.017 & 88 & 0.021 & 0.002 & 0.093 & 369 & 0.012 & 0.001 & 0.032 & 291 & 0.000 & 0.000 & 0.005 & 254 \\
\hline TREO $^{1}$ & 0.130 & 0.037 & 0.302 & 88 & 0.185 & 0.022 & 0.383 & 369 & 0.049 & 0.015 & 0.115 & 291 & 0.001 & 0.000 & 0.014 & 254 \\
\hline
\end{tabular}

TREO, Total rare earth oxide. 
Table 4. Mean rare earth oxide (REO) concentrations and relative REO distribution of seabed mineral and the select land-based rare earth element (REE) deposits.

\begin{tabular}{|c|c|c|c|c|c|c|c|c|c|c|c|c|}
\hline \multirow{2}{*}{\multicolumn{2}{|c|}{ Rare Earth Oxide }} & \multicolumn{3}{|c|}{ Seabed Mineral Resources } & \multicolumn{7}{|c|}{ Land-Based REE Deposits } & \multirow{2}{*}{$\begin{array}{l}\text { REO Price } \\
\text { (USD/kg) }\end{array}$} \\
\hline & & $\begin{array}{l}\text { Polymetallic } \\
\text { Nodule }\end{array}$ & $\begin{array}{c}\text { Ferromanganese } \\
\text { Crust }\end{array}$ & $\begin{array}{l}\text { Deep-Sea } \\
\text { Sediment }\end{array}$ & $\begin{array}{l}\text { Mt. } \\
\text { Pass }\end{array}$ & $\begin{array}{l}\text { Mount } \\
\text { Weld }\end{array}$ & $\begin{array}{c}\text { Nolans } \\
\text { Bore }\end{array}$ & Longnan & $\begin{array}{c}\text { Bayan } \\
\text { Obo }\end{array}$ & $\begin{array}{c}\text { Bear } \\
\text { Lodge }\end{array}$ & $\begin{array}{l}\text { Strange } \\
\text { Lake }\end{array}$ & \\
\hline \multirow{11}{*}{$\begin{array}{c}\text { REO } \\
\text { concentration (\%) }\end{array}$} & $\mathrm{La}_{2} \mathrm{O}_{3}$ & 11.54 & 13.74 & 14.68 & 33.2 & 25.5 & 19.74 & 7.8 & 25.5 & 30.37 & 4.58 & 2.1 \\
\hline & $\mathrm{Ce}_{2} \mathrm{O}_{3}$ & 49.96 & 50.21 & 16.97 & 49.1 & 46.74 & 47.53 & 2.4 & 50.0 & 45.5 & 11.95 & 1.9 \\
\hline & $\mathrm{Pr}_{2} \mathrm{O}_{3}$ & 3.32 & 2.44 & 4.61 & 4.38 & 5.32 & 5.82 & 2.4 & 4.0 & 4.65 & 1.36 & 55.5 \\
\hline & $\mathrm{Nd}_{2} \mathrm{O}_{3}$ & 13.32 & 10.45 & 19.05 & 12. & 18.5 & 21.2 & 9.0 & 17.0 & 15.82 & 4.26 & 40.5 \\
\hline & $\mathrm{Sm}_{2} \mathrm{O}_{3}$ & 3.12 & 2.12 & 4.23 & 0.8 & 2.27 & 2.37 & 3.0 & 1.5 & 1.83 & 2.07 & 2.1 \\
\hline & $\mathrm{Eu}_{2} \mathrm{O}_{3}$ & 0.76 & 0.82 & 1.26 & 0.1 & 0.21 & 0.4 & - & 0.2 & 0.35 & 0.15 & 104.3 \\
\hline & $\mathrm{Gd}_{2} \mathrm{O}_{3}$ & 3.16 & 2.6 & 4.55 & 0.2 & 0.75 & 1.0 & 4.4 & 0.4 & .74 & 2.45 & 11.2 \\
\hline & $\mathrm{Tb}_{2} \mathrm{O}_{3}$ & 0.49 & 0.37 & 0.71 & - & - & 0.08 & 0.9 & 0.25 & 0.05 & 0.33 & 440.0 \\
\hline & $\mathrm{Dy}_{2} \mathrm{O}_{3}$ & 2.55 & 2.19 & 3.98 & - & - & 0.33 & 5.3 & - & 0.16 & 8.24 & 227.5 \\
\hline & $\mathrm{Y}_{2} \mathrm{O}_{3}$ & 8.42 & 11.55 & 24.58 & - & - & 1.32 & 56.2 & 0.3 & - & 52.78 & 4.3 \\
\hline & Others ${ }^{1}$ & 3.37 & 3.5 & 5.39 & 0.22 & 0.29 & 0.21 & 2.37 & - & 0.07 & 11.73 & - \\
\hline \multirow{3}{*}{$\begin{array}{l}\text { Relative REO } \\
\text { distribution (\%) }\end{array}$} & $\mathrm{LC}^{2}$ & 63.64 & 66.27 & 33.45 & 82.48 & 72.76 & 67.41 & 11.16 & 76.15 & 76.27 & 18.75 & \\
\hline & $\mathrm{NPD}^{2}$ & 19.85 & 15.63 & 29.21 & 16.42 & 23.99 & 27.41 & 18.27 & 21.18 & 20.74 & 15.72 & \\
\hline & SEGTY $^{2}$ & 16.5 & 18.1 & 37.33 & 1.1 & 3.25 & 5.18 & 70.58 & 2.67 & 3. & 65.53 & \\
\hline \multirow{5}{*}{$\begin{array}{c}\text { Basket price } \\
\text { (USD/kg) }\end{array}$} & LC & 1.19 & 1.24 & 0.63 & 1.63 & 1.42 & 1.32 & .21 & 1.49 & 1.5 & 0.32 & \\
\hline & NPD & 13.03 & 10.57 & 19.32 & 7.29 & 10.45 & 12.57 & 17.03 & 9.11 & 9.35 & 21.23 & \\
\hline & SEGTY & 3.71 & 3.33 & 6.1 & 0.14 & 0.35 & 0.99 & 6.96 & 1.4 & 0.71 & 4.2 & \\
\hline & $\mathrm{TBP}^{3}$ & 17.93 & 15.14 & 26.05 & 9.06 & 12.22 & 14.87 & 24.21 & 11.99 & 11.56 & 25.75 & \\
\hline & TREO $^{4}(\%)$ & 0.13 & 0.19 & 0.05 & $8.0-8.9$ & $7.9-15.5$ & 2.8 & $0.05-0.2$ & 6 & $2.6-3.2$ & $0.97-1.16$ & \\
\hline
\end{tabular}

${ }^{1}$ Other REO: $\mathrm{Ho}_{2} \mathrm{O}_{3}, \mathrm{Er}_{2} \mathrm{O}_{3}, \mathrm{Tm}_{2} \mathrm{O}_{3}, \mathrm{Yb}_{2} \mathrm{O}_{3}$, and $\mathrm{Lu}_{2} \mathrm{O}_{3} ;{ }^{2} \mathrm{LC}=\mathrm{La}$ and Ce; NPD = Nd, Pr and Dy; SEGTY = Sm, Eu, Gd, Y, and Tb; ${ }^{3}$ Total basket price; ${ }^{4}$ Total rare earth oxide; ${ }^{5} \mathrm{REO}$

prices as listed by Argus metal prices (average annual 2015 prices [30]). References for the REO data of the land-based REE deposits are listed in Table S1, except for Longnan deposit [31] 


\subsection{Ferromanganese Crusts}

Tellurium is the most enriched critical metal in the ferromanganese crusts with an average concentration of $56 \mathrm{mg} / \mathrm{kg}$, which is $\sim 10,000 \times$ higher than in average continental crust (Table S1; Figure 2B). Nickel and Co have traditionally been targets of resource exploitation and are the second-most enriched critical metals in the crusts. The $\mathrm{Pt}$ contents of the crusts range between 165-909 $\mu \mathrm{g} / \mathrm{kg}$ (average $364 \mu \mathrm{g} / \mathrm{kg}$ ), and are $\sim 150 \times$ more enriched than the composition of average crust (Figure $2 \mathrm{~B}$ ). The concentrations of $\mathrm{Rh}, \mathrm{Ir}$, and $\mathrm{Ru}$ are $16-42 \times$ more enriched in the crusts than in average continental crust, but are similar to the PGE contents of seamounts outside of the Korean tenements $(\mathrm{Pt}=9-22 \mu \mathrm{g} / \mathrm{kg}, \mathrm{Rh}=71-333 \mu \mathrm{g} / \mathrm{kg}, \mathrm{Ru}=8-21 \mu \mathrm{g} / \mathrm{kg}$ [26]). The concentrations of critical metals $\mathrm{Bi}, \mathrm{Tl}, \mathrm{Mo}, \mathrm{Sb}, \mathrm{Mn}$, and $\mathrm{W}$ are $\sim 100 \times$ higher than in average continental crust (Figure 2B).

The TREO contents of the ferromanganese crusts vary between $0.086-0.387 \%$, with an average value of $0.185 \%$. Similarly to the polymetallic nodules, the RRD of the ferromanganese crusts comprises 66.3\% LC, 10.6\% NPD, and 3.3\% SEGTY (Table 3). NPD, SEGTY, and LC have the highest, second-highest, and lowest basket price, respectively (10.6 USD $/ \mathrm{kg}, 3.3 \mathrm{USD} / \mathrm{kg}$, and $1.2 \mathrm{USD} / \mathrm{kg}$, respectively; Table 4; Figure 3). The TREO contents of the ferromanganese crusts (average $0.185 \%$ ) are higher than that of the one polymetallic nodule that was analyzed in this study $(0.13 \%$; Table 3$)$; however, the total basket price of TREO from the ferromanganese crusts is slightly lower $(15.1 \mathrm{USD} / \mathrm{kg})$ than that of the polymetallic nodules (17.9 USD $/ \mathrm{kg})$, owing to the high and low NPD and LC contents, respectively, of the polymetallic nodules (Table 4 ).
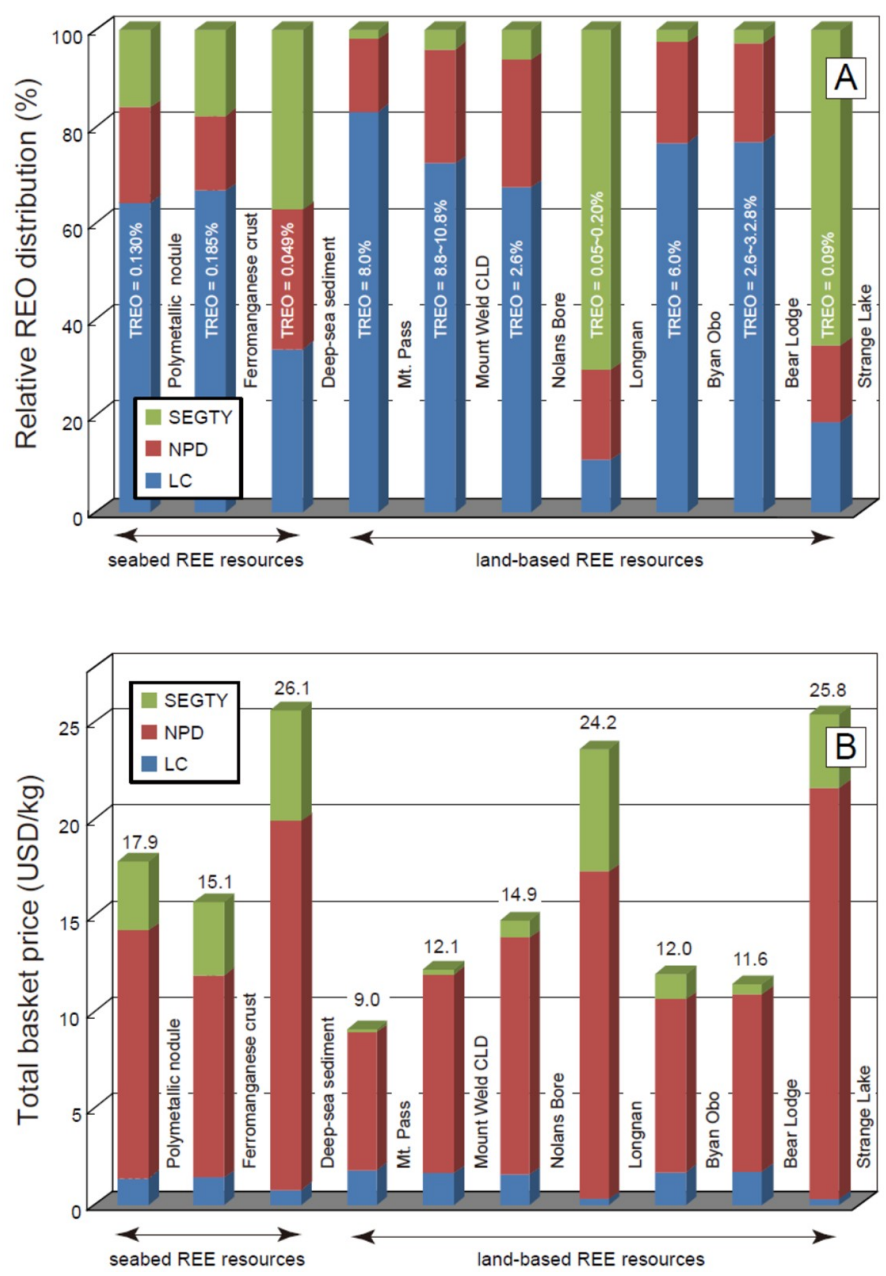

Figure 3. (A) Relative REO distribution of seabed and land-based REE deposits. (B) Total basket price (USD/kg) of REO from seabed and land-based REE deposits. LC = La and Ce; NPD = Nd, Pr and Dy; SEGTY $=\mathrm{Sm}, \mathrm{Eu}, \mathrm{Gd}, \mathrm{Y}$ and Tb, TREO = total rare earth oxide. 


\subsection{Deep-Sea Sediments}

In contrast to the polymetallic nodules and ferromanganese crusts, the critical metal contents of the deep-sea sediments are low. The most enriched element is $\mathrm{Sb}$ (average two $\mathrm{mg} / \mathrm{kg}$ ), with concentrations $10 \times$ higher than in average continental crust. The concentrations of $\mathrm{Co}$ and $\mathrm{Ni}$ are consistent with those of average continental crust (Table 2; Figure 2C). The very low concentrations of critical metals in the deep-sea sediments may reflect low $\mathrm{MnO}$, Fe-oxyhydroxides, and/or CFA contents.

The TREO contents of the deep-sea sediments range between $0.015-0.115 \%$, with an average content of $0.049 \%$. The average TREO contents from the cores of which sampling sites are widespread, range from $0.026 \%$ to $0.076 \%$, except for one PC sample (average TREO; $0.093 \%$ ). The TREO contents of the deep-sea sediments are $\sim 1 / 3$ that of the polymetallic nodules and ferromanganese crusts (Table 3 ). The deep-sea sediments comprise 37.3\% SEGTY, 33.5\% LC, and 29.2\% NPD. Despite their lower average TREO contents, the total basket price of the deep-sea sediments is $\sim 200 \%$ ( $26.1 \mathrm{USD} / \mathrm{kg}$ ) more than that of the nodules and crusts, because the amount of NPD and SEGTY in the former is double, and the amount of LC is half compared with the latter (Table 4; Figure 3).

The REE contents of the core samples vary vertically (i.e., with depth) due to changes in the RRD. We use four PC (220-340 cm core length) and two BC samples (50 cm core length) to highlight the changes in RRD and basket price with depth. Both NPD and SEGTY show increasing trends with depth, whereas LC shows a decreasing trend (Table 5; Figure 4).

Table 5. Average rare earth oxide grade and relative REO distribution of units I, II, and III of the deep-sea sediment samples.

\begin{tabular}{|c|c|c|c|c|}
\hline \multirow{2}{*}{\multicolumn{2}{|c|}{ Rare Earth Oxide }} & \multicolumn{3}{|c|}{ Deep-Sea Sediments } \\
\hline & & Unit I (N = 9) & Unit II (N = 79) & Unit III $(\mathbf{N}=37)$ \\
\hline \multirow{11}{*}{$\begin{array}{c}\text { REO } \\
\text { concentration }(\%)\end{array}$} & $\mathrm{La}_{2} \mathrm{O}_{3}$ & 13.88 & 14.14 & 16.76 \\
\hline & $\mathrm{Ce}_{2} \mathrm{O}_{3}$ & 28.52 & 25.7 & 10.17 \\
\hline & $\mathrm{Pr}_{2} \mathrm{O}_{3}$ & 4.4 & 4.47 & 5.26 \\
\hline & $\mathrm{Nd}_{2} \mathrm{O}_{3}$ & 19.1 & 18.88 & 22.1 \\
\hline & $\mathrm{Sm}_{2} \mathrm{O}_{3}$ & 4.08 & 4.1 & 4.74 \\
\hline & $\mathrm{Eu}_{2} \mathrm{O}_{3}$ & 1.32 & 1.26 & 1.33 \\
\hline & $\mathrm{Gd}_{2} \mathrm{O}_{3}$ & 4.13 & 4.4 & 5.2 \\
\hline & $\mathrm{Tb}_{2} \mathrm{O}_{3}$ & 0.67 & 0.68 & 0.77 \\
\hline & $\mathrm{Dy}_{2} \mathrm{O}_{3}$ & 3.86 & 3.86 & 4.52 \\
\hline & $\mathrm{Y}_{2} \mathrm{O}_{3}$ & 20.04 & 22.51 & 29.15 \\
\hline & Others $^{1}$ & 4.77 & 5.05 & 5.92 \\
\hline \multirow{3}{*}{$\begin{array}{c}\text { Relative REO } \\
\text { distribution (\%) }\end{array}$} & $\mathrm{LC}^{2}$ & 42.41 & 39.84 & 26.93 \\
\hline & $\mathrm{NPD}^{2}$ & 27.35 & 27.22 & 31.88 \\
\hline & SEGTY $^{2}$ & 30.24 & 32.94 & 41.19 \\
\hline \multirow{5}{*}{$\begin{array}{l}\text { Basket price } \\
\text { (USD/kg) }\end{array}$} & LC & 0.8 & 0.75 & 0.51 \\
\hline & NPD & 18.09 & 18.0 & 20.91 \\
\hline & SEGTY & 5.48 & 5.55 & 6.35 \\
\hline & $\mathrm{TBP}^{3}$ & 24.36 & 24.3 & 27.78 \\
\hline & $\mathrm{TREO}^{4}(\%)$ & 0.029 & 0.035 & 0.088 \\
\hline
\end{tabular}

${ }^{1}$ Other REO: $\mathrm{Ho}_{2} \mathrm{O}_{3}, \mathrm{Er}_{2} \mathrm{O}_{3}, \mathrm{Tm}_{2} \mathrm{O}_{3}, \mathrm{Yb}_{2} \mathrm{O}_{3}$, and $\mathrm{Lu}_{2} \mathrm{O}_{3} ;{ }^{2} \mathrm{LC}=\mathrm{La}$ and Ce; NPD = Nd, Pr and Dy; SEGTY = Sm, Eu, $\mathrm{Gd}, \mathrm{Y}$, and $\mathrm{Tb} ;{ }^{3}$ Total basket price; ${ }^{4}$ Total rare earth oxide.

Furthermore, the TREO contents of the samples increase with depth. In particular, the boundaries between units are marked by changes in the RRD, total price, and TREO concentration (Figure 4). In all six samples, the TREO contents and total basket prices increase from units I to III (Table 5). Within Unit III, which is the lowermost layer, the LC content decreases sharply, whereas the NPD and SEGTY contents increase. The low LC contents in Unit III may reflect an overall increase in the TREO concentration of Unit III compared with units I and II, as the Ce concentrations of the three layers are consistent (Table 2). Interestingly, the total basket price of Unit III is higher than that of the 
polymetallic nodules and ferromanganese crusts, even though its TREO contents are lower. In order to elucidate the characteristics of the geochemical fractions of REE, the average REE composition of the seabed mineral deposits are normalized to the average composition of Post-Archean Australian Shales (PAAS). In case of the deep-sea sediment, the shale-normalized REE values of each unit are provided to identify the ratio variations according to core depth. The shale-normalized REE patterns in Figure 5 reveal that the highest total basket prices of Unit III correspond with the lowest Ce concentrations (i.e., samples with a negative Ce anomaly).
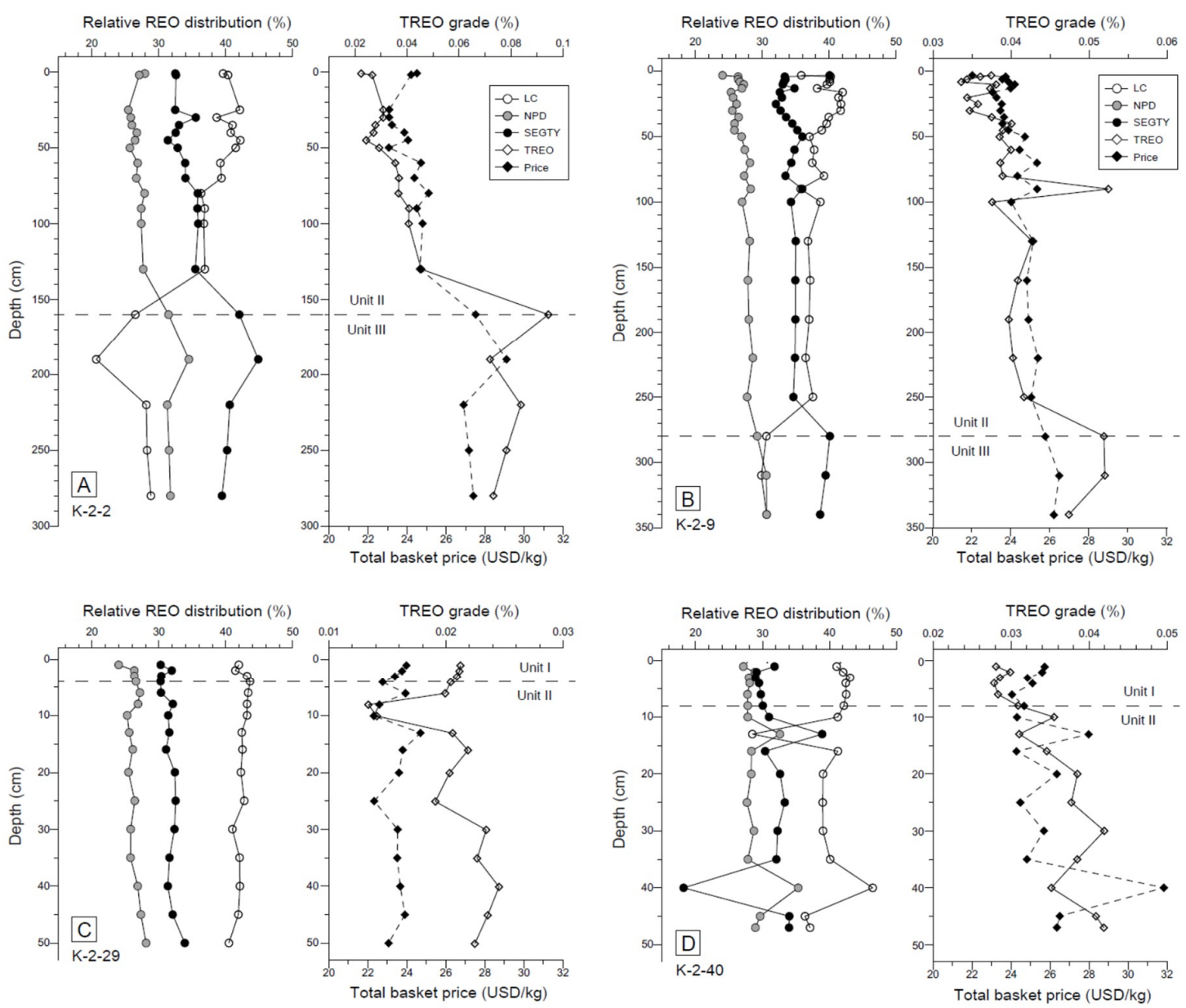

Figure 4. Relative rare earth oxide distributions and basket prices from deep-sea sediment core samples analyzed in this study. (A) and (B) Piston cores. (C) and (D) Box cores. LC = La and Ce; NPD = Nd, Pr and Dy; SEGTY = Sm, Eu, Gd, Y and Tb.

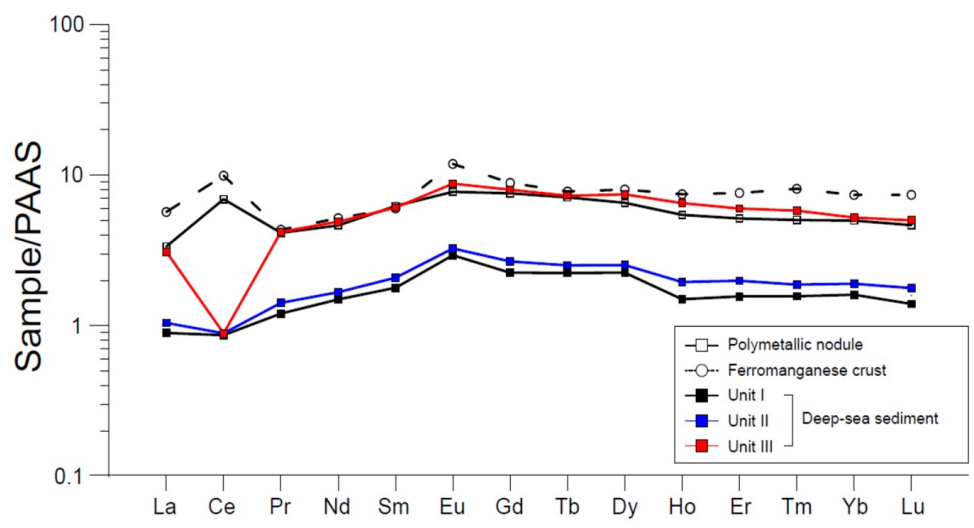

Figure 5. Post-Archean Australian Shales (PAAS)-normalized REE distribution patterns of seabed REE resources. PAAS $=$ Post-Archean Australian shales. 


\subsection{Seafloor Massive Sulfides}

Critical metals such as Se and In, and precious metals such as Au and Ag are typically concentrated within SMS. In hydrothermal sulfides, Se is the most abundant (average $=10.8 \mathrm{mg} / \mathrm{kg}$, up to $60 \mathrm{mg} / \mathrm{kg}$ ), and is enriched relative to average continental crust by a factor of 216 (Figure 2D). The Ba, Sb, and Tl contents of the sulfides are $100 \times$ higher than those of average continental crust. Hydrothermal sulfide ores in the North Fiji and Lau basins have an average In concentration of $1.3 \mathrm{mg} / \mathrm{kg}(0.05-41.2 \mathrm{mg} / \mathrm{kg})$, which is $26 \times$ higher than that of average continental crust (Table 2). Gold and Ag are valuable commodities from SMS. Ores from Tonga and Fiji have average Au and Ag grades of $8.7 \mathrm{~g} / \mathrm{t}$ and $202.7 \mathrm{~g} / \mathrm{t}$, respectively (Table 2; Figure 2D). Gold concentrations in hydrothermal ores from the Tonga Arc range between $0.5-30 \mathrm{~g} / \mathrm{t}$, with an average value of $5.5 \mathrm{~g} / \mathrm{t}$. The REE contents of SMS ores from the present study area are too low (average REO $<0.004 \%$ ) to be considered as a REE reserve at present (Table 3).

\section{Discussion}

\subsection{Low-Grade, Large-Tonnage Deposits}

The ore and TREO tonnage, and TREO grade of 75 land-based REE deposits are compiled in Table S1 and presented in Figure 6. Approximately $51 \%$ of the deposits are classified as large deposits, as they contain $0.1 \mathrm{Mt}$ of TREO and have continuously produced rare earth elements for $>20$ years at a rate of $5000 \mathrm{t} /$ year REO. Of these large deposits, 53\% have yielded 0.1-1.0 Mt TREO and $47 \%$ have yielded $>1.0 \mathrm{Mt}$ TREO, but overall, $60 \%$ of the large deposits have a relatively low TREO grade $(<2 \%)$.

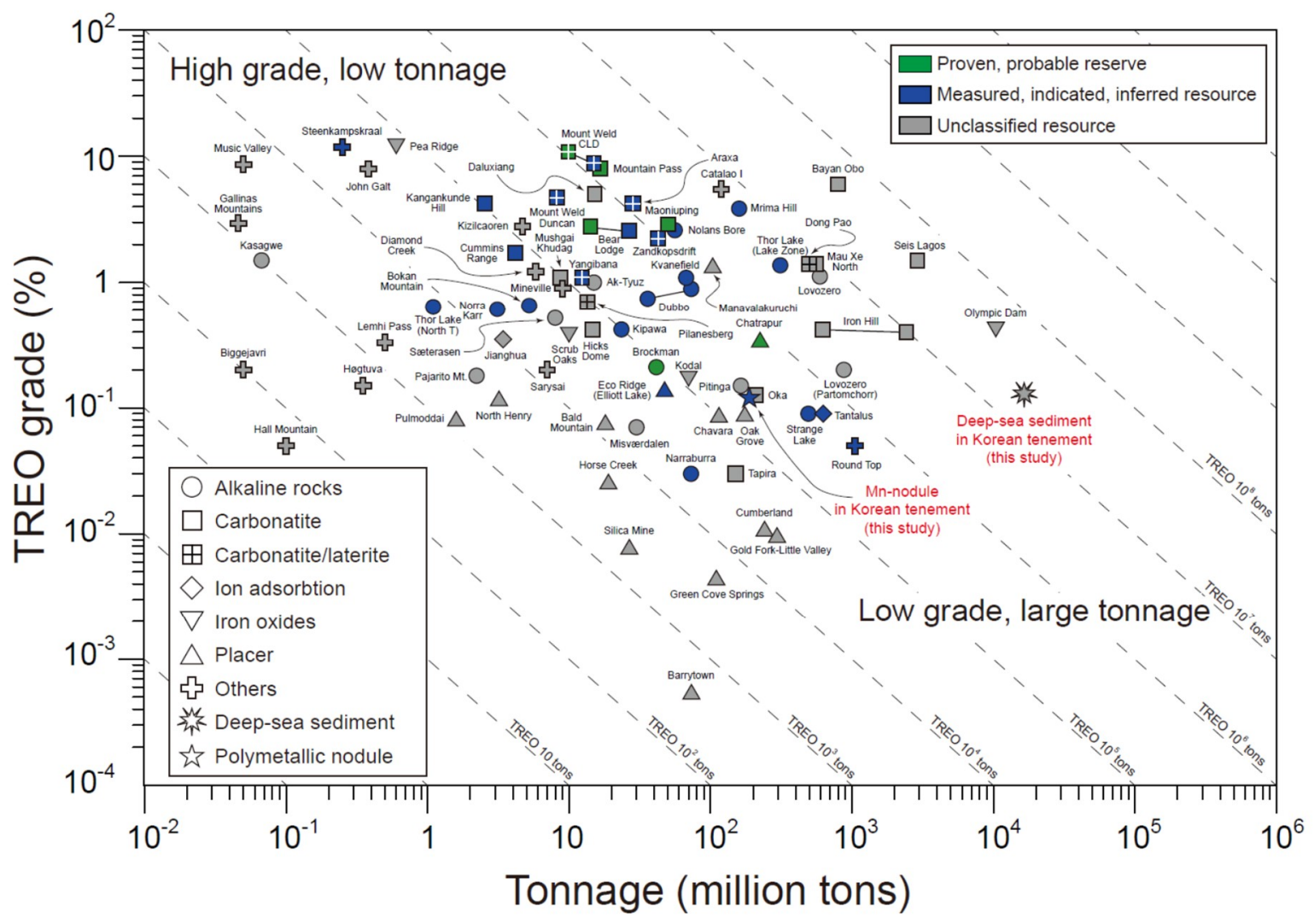

Figure 6. TREO grade and ore tonnage of selected land-based REE deposits with a preliminary resource estimation of polymetallic nodules and deep-sea sediments.

The estimated TREO yield from REE deposits within the Lovozero Alkaline Complex in Russia is 1.8-6.6 Mt. The largest ore tonnage (593-877 Mt) comes from a regional-scale REE-bearing batholith 
and has been attributed to its high TREO tonnage, despite having a low TREO grade (0.2-1.1\%). In contrast, the ore tonnage of the Mount Weld Central Lanthanide Deposit (CLD) is relatively low (9.9-15 Mt), but it has a high TREO grade (8.8-10.8\%); consequently, the TREO tonnage is also large (1.1-1.3 Mt; Table S1).

The ore tonnage of polymetallic nodules over a $25,000 \mathrm{~km}^{2}$ area within the Korean tenements is $188 \mathrm{Mt}$, with an average nodule density of $10.4 \mathrm{~kg} / \mathrm{m}^{2}$ [32]. The average TREO grade of the polymetallic nodules is $0.13 \%$, meaning that the TREO content of the nodule deposit within a $25,000 \mathrm{~km}^{2}$ area is $~ 0.23 \mathrm{Mt}$ (Table S1; Figure 6). The total TREO tonnage of polymetallic nodules within all of the Korean tenements $\left(75,000 \mathrm{~km}^{2}\right)$ is $\sim 1 \mathrm{Mt}$, which is consistent with that of a large deposit. Assuming that the deep-sea sediments cover an area of the size as that which is estimated for the polymetallic nodules (i.e., $25,000 \mathrm{~km}^{2}$ ), and that the sediments contain a one meter-thick REE-bearing layer with a dry bulk density of $0.66 \mathrm{~g} / \mathrm{cm}^{3}$ [4], the ore tonnage of the deep-sea sediments is estimated to be $16,500 \mathrm{Mt}$. If the average TREO content of the area is $0.049 \%$, a significant TREO yield (eight Mt) could be obtained from the REE-bearing sediments. It has the potential to take $0.2 \%$ of the global REO resources estimated in 2017 (478 Mt, [27]). According to Kato et al. [4], the total rare earth element and yttrium contents of deep-sea muds in the CCZ are $\sim 400-700 \mathrm{mg} / \mathrm{kg}$, which is consistent with the results of this study. This observation suggests that the total TREO tonnage from deep-sea sediments within the Korean tenements in the CCZ is significantly higher than eight Mt. A high TREO grade and low Ce concentration in deeper layers of the sediment (i.e., Unit III) may result in a large TREO tonnage. Therefore, we classify the deep-sea mineral deposits as low-grade mineral deposits with a large TREO tonnage, which is analogous to land-based porphyry copper deposits. Porphyry copper deposits are important sources of copper, and are favored by large mining companies as they represent long-term investments with predictable ore grade and few challenges during ore processing.

Currently, it is difficult to evaluate the resource potential of ferromanganese crusts because of the limited data, despite their TREO grades being consistent with those of polymetallic nodules (average $0.185 \%$ ). Ferromanganese crusts also have potential as low-grade mineral deposits with a large TREO tonnage, depending on the size of the exploration area.

\subsection{Relative REO Distributions of Seabed Mineral Resources}

Land-based REE deposits that are currently being exploited or under exploration have variable TREO grades (0.01-12.0\%; Table S1). World-class land-based REE deposits in the production stage (e.g., Mount Weld CLD, Mountain Pass, and Nolans Bore) typically yield TREO tonnages of $>$ one Mt and TREO grades of up to $10 \%$ (Figure 6).

In comparison, the deep-sea mineral resources that were analyzed in this study have a lower and narrower TREO grade (0.049-0.185\%), and are consistent with the TREO grades of some land-based REE deposits (0.01-0.2\%; Table 3; Figure 6). The TREO grade and thus economic value of land-based REE deposits can be evaluated by their mineralization type (i.e., host rocks and REE-bearing minerals), TREO content, target metal value, and the types of co-product and by-product metals. The RRD of REE-bearing ores is particularly critical to the economic value of a deposit. Zhou et al. [27] highlighted that successful REE exploitation is dependent on tonnage, ore grade, RRD, and the basket value of the REE deposit [27].

NPD and SEGTY from deep-sea mineral deposits have high basket prices and occur in higher proportions than in land-based deposits (Table 4; Figure 3A). The ion adsorption REE mines in the Longnan Area in China yield a high total basket price (26.8 USD/kg) and a low TREO grade $(\sim 0.2 \%)$, which is consistent with deep-sea mineral resources. The similarities in the RRD of deep-sea mineral deposits and ion adsorption REE mines are attributed to their high NPD and SEGTY contents, which have high basket prices (Figure 3B). Of note, the primary mechanism of REE precipitation within polymetallic nodule and ferromanganese crust is the absorption of Mn-oxyhydroxides or Fe-oxyhydroxides, forming carbonate complex ion species (e.g., $\left.\operatorname{HREE}\left(\mathrm{CO}_{3}\right)_{2}{ }^{-}, \mathrm{LREE}\left(\mathrm{CO}_{3}\right)^{+}[33]\right)$. This process suggests that REE is not a part of crystal lattice of host minerals. 
Compared with other seabed mineral resources, deep-sea sediments have higher NPD and SEGTY contents, owing to their low Ce concentrations (Table 4; Figure 5). Assuming that REE precipitation is consistent across all of the sediment layers, each layer should theoretically have a similar RRD and basket price; however, the lowermost layer (Unit III) has a higher proportion of NPD and SEGTY than the other layers (Table 5). The higher proportions of NPD and SEGTY in Unit III are a result of the low LC and thereby low Ce contents within this layer, as indicated by the large negative Ce anomaly in Unit III (Figure 5). The REE pattern of apatite, which inherits typical negative Ce anomalies from seawater, mainly regulates the REE content of deep-sea sediment $[7,34,35]$. The lowermost layer has greater TREO contents and more pronounced negative Ce anomalies owing to the Ca-phosphate grains taking up REE from ambient seawater or pore water near the seafloor under the very low sedimentation rate $[7,35,36]$. Therefore, we infer that deeper REE-bearing sediments have lower Ce contents, and that the greater the TREO concentration, the higher the basket price and ore value.

The polymetallic nodules and ferromanganese crusts have higher TREO contents than the deep-sea sediments (Table 4; Figure 5); however, the basket price of the nodules and crusts is lower than that of the deep-sea sediments, owing to their higher LC contents (i.e., higher Ce concentrations). High Ce concentrations are interpreted to reflect the oxidative scavenging of Ce by Mn oxides, resulting in positive Ce anomalies [37]. Therefore, the lower total basket price of the polymetallic nodules and ferromanganese crusts is the result of the high Ce contents, which reflect the rapid Ce uptake and precipitation by Ce oxidation.

The cost of extracting REEs from an ore is dependent on the type of REE-bearing host mineral phases. REEs in ion adsorption rare earth deposits can be extracted simply by open-pit techniques with no to minimal dressing. Therefore, a low-grade (TREO $=0.05-0.20 \%)$ land-based deposit may involve relatively low extraction costs [27,38]. The world-class Mount Weld CLD and Mountain Pass REE deposits ( $>8 \%$ TREO) are hosted within carbonatites and contain REE-bearing minerals such as xenotime and bastnäsite. The cost of extracting REEs from these host minerals is high, as the REE-bearing host minerals must be crushed and pulverized. Furthermore, REE-bearing ore of the ion-adsorption type contains low amounts of radioactive elements (e.g., Th and U), which differs from placer REE deposits [18]. Deep-sea mineral deposits also show low Th and U concentrations (Table 2). Results of leaching experiments of REE from deep-sea sediment by monovalent salt solution [4] imply that REE is not a part of the crystal lattice. It means there is no need to pulverize REE-bearing host minerals and extract REEs by aggressive conditions such as the recovery process of land-based ion-absorption REE deposits. Therefore, these deposits are favored by the low cost of ore processing.

\subsection{Other Rare Metals}

The polymetallic nodules have high REE, Pd, and Pt contents. Nodules recovered from the central Pacific and Indian oceans contain 120-930 $\mathrm{gg} / \mathrm{kg}$ and $3668 \mu \mathrm{g} / \mathrm{kg}$ (average) $\mathrm{Pt}$, respectively [15]. Tellurium is the most enriched critical metal within the ferromanganese crusts, with an average concentration of $57 \mathrm{mg} / \mathrm{kg}$, which is $10,000 \times$ higher than in average continental crust. PGEs are also valuable critical metals. The SMS deposits are characterized by high Se, In, and precious metal contents, and very low REO contents.

The economic feasibility of land-based REE-bearing polymetallic deposits is dependent on the amount and diversity of co-product and by-product metals (e.g., $\mathrm{Fe}, \mathrm{Hf}, \mathrm{Nb}$ ), in addition to the factors mentioned above (e.g., tonnage, ore grade, and RRD). For example, the Bayan Obo and Lovozero mines currently produce REEs as a by-product of iron and niobium production, respectively. Olympic Dam is one of the largest iron deposits globally, and although REEs are not currently processed, a significant TREO tonnage has been estimated.

To date, there have been no successful attempts to mine $\mathrm{Ni}, \mathrm{Cu}$, and $\mathrm{Mn}$ as major commodities on a commercial scale from polymetallic nodules and ferromanganese crusts. Critical and precious metals and REE from seabed mineral deposits are important by-products of these primary commodities and have the potential to enhance the economic feasibility of extracting major commodities. 


\section{Conclusions}

Polymetallic nodules, ferromanganese crusts, SMS, and deep-sea sediments are potential critical metal sources. We evaluated the critical metal potential of these deposits in terms of TREO grade, ore and TREO tonnage, RRD, and basket price. The average TREO contents of the polymetallic nodules and ferromanganese crusts are $0.13 \%$ and $0.185 \%$, respectively. The total basket price of the polymetallic nodules is slightly higher than that of the ferromanganese crusts because of their higher NPD and lower LC contents. The TREO grades of the deep-sea sediments range between $0.015-0.115 \%$, with an average grade of $0.049 \%$. The average TREO content of the deep-sea sediments is $\sim 1 / 3$ that of the nodules and crusts, yet its total basket price is approximately double. This is because the deep-sea sediments contain approximately double the NPD and SEGTY contents, and half the LC contents of the crusts and nodules. Furthermore, the TREO content and total basket price of the deep-sea sediments increase with depth (i.e., from Unit I to III). Within Unit III, the LC content decreases sharply, whereas the NPD and SEGTY contents increase. Unit III yields the highest total basket price, owing to its low Ce concentrations. Compared with land-based REE deposits, the total basket price of the deep-sea mineral deposits is higher because of their high NPD and SEGTY contents. Te, Mo, Co, and Ni are $>100 \times$ more enriched in the polymetallic nodules and ferromanganese crusts than in average continental crust. The nodules and crusts are also enriched in PGEs. The SMS are enriched in Se, In, and precious metals such as Au and Ag, but the REE and other critical metal contents of the recovered sulfide ores in the survey area are too low to be considered a reserve at present. The average TREO content of the polymetallic nodules is $0.13 \%$, with a total ore tonnage of $188 \mathrm{Mt}$, equating to an estimated tonnage of $0.23 \mathrm{Mt}$ in 25,000 $\mathrm{km}^{2}$ area. The total TREO tonnage of polymetallic nodules from all Korean tenements is estimated as $\sim 1 \mathrm{Mt}$.

In REE-bearing deep-sea sediment, 16,500 Mt of sediment at a TREO concentration of $0.049 \%$ equates to a gigantic TREO tonnage of eight Mt. A comparison with land-based REE deposits suggests that these deep-sea mineral deposits are low-grade mineral deposits with a large tonnage.

The NPD and SEGTY components of the deep-sea mineral deposits, for which the basket prices are high, occur in high proportions, similar to ion adsorption REE deposits on land. Similarities in RRD are observed between the deep-sea mineral deposits and ion adsorption REE deposits. The latter are interpreted as forming by REE precipitation due to the adsorption of Mn-oxyhydroxides or Fe-oxyhydroxides, forming carbonate complex ion species. Compared with other seabed mineral resources, the deep-sea sediments have higher NPD and SEGTY contents, and therefore lower Ce contents, and a higher TREO basket value. REE that is not a part of the crystal lattice of host minerals within deep-sea mineral deposits is favorable for mining. It means there is no requirement to crush or pulverize the REE-bearing host minerals during ore processing, and the low Th and U concentrations do not pose environmental risks. REE and critical metals within deep-sea mineral deposits are important by-products and co-products of primary commodities that may enhance the economic feasibility of extracting major commodities.

Supplementary Materials: Data for 75 land-based REE deposits are available online (http:/ /www.mdpi.com/ 2075-163X/9/1/3/s1). Table S1: Total rare earth oxide grades and ore tonnage of 75 land-based rare earth deposits with the polymetallic nodule and deep-sea sediment deposits; Figure S1: Discrimination diagrams using the relationship between (a) $\mathrm{Ce}_{\mathrm{SN}} / \mathrm{Ce}_{\mathrm{SN}}{ }^{*}$ ratio vs. $\mathrm{Nd}$ concentration and (b) $\mathrm{Ce}_{\mathrm{SN}} / \mathrm{Ce}_{\mathrm{SN}}{ }^{*}$ ratio vs. $\mathrm{Y}_{\mathrm{SN}} / \mathrm{Ho}_{\mathrm{SN}}$ ratio in individual layers of nodule and crust samples, where $\mathrm{Ce}_{\mathrm{SN}}{ }^{*}=0.5 \times \mathrm{La}_{\mathrm{SN}}+0.5 \times \operatorname{Pr}_{\mathrm{SN}}$ and $\mathrm{SN}=\mathrm{shale}$ (PAAS) normalised.

Author Contributions: S-J.P. was responsible for conceptualization and methodology. S-J.P., I.S., K-Y.L. and K.H. analyzed the samples and organized the data. S-J.P. wrote the paper.

Funding: This work was financially supported by funds from the Korea Institute of Ocean Science and Technology (PE99642, PE99616 and PM57061) and Ministry of Oceans and Fisheries (19992001).

Acknowledgments: The authors thank the two anonymous reviewers for providing useful suggestions and comments on this manuscript.

Conflicts of Interest: The authors declare no conflict of interest. 


\section{References}

1. Deloitte Sustainability; British Geological Survey; Bureau de Recherches Géologiques et Minières; Netherlands Organisation for Applied Scientific Research. Study on the review of the list of Critical Raw Materials. Criticality Assessments. 2017. Available online: https:/ / publications.europa.eu/en/publicationdetail/- / publication/08fdab5f-9766-11e7-b92d-01aa75ed71a1/language-en (accessed on 1 March 2018).

2. Graedel, T.E.; Harper, E.; Nassar, N.T.; Nuss, P.; Reck, B.K. Criticality of metals and metalloids. Proc. Natl. Acad. Sci. 2015, 112, 4257-4262. [CrossRef] [PubMed]

3. Hein, J.R.; Conrad, T.A.; Staudigel, H. Seamount mineral deposits a source of rare metals for high-technology industries. Oceanography 2010, 23, 184-189. [CrossRef]

4. Kato, Y.; Fujinaga, K.; Nakamura, K.; Takaya, Y.; Kitamura, K.; Ohta, J.; Toda, R.; Nakashima, T.; Iwamori, H. Deep-sea mud in the Pacific Ocean as a potential resource for rare-earth elements. Nat. Geosci. 2011, 4, 535-539. [CrossRef]

5. Hein, J.R.; Cherkashov, G.A. Preface for ore geology reviews special issue: Marine mineral deposits: New resources for base, precious, and critical metals. Ore Geol. Rev. 2017, 87, 1-2. [CrossRef]

6. Chakhmouradian, A.R.; Wall, F. Rare earth elements: Minerals, mines, magnets (and more). Elements 2012, 8, 333-340. [CrossRef]

7. Yasukawa, K.; Nakamura, K.; Fujinaga, K.; Iwamori, H.; Kato, Y. Tracking the spatiotemporal variations of statistically independent components involving enrichment of rare-earth elements in deep-sea sediments. Sci. Rep. 2016, 6, 29603. [CrossRef] [PubMed]

8. Lusty, P.A.; Hein, J.R.; Josso, P. Formation and occurrence of ferromanganese crusts: Earth's storehouse for critical metals. Elements 2018, 14, 313-318. [CrossRef]

9. Deng, Y.; Ren, J.; Guo, Q.; Cao, J.; Wang, H.; Liu, C. Rare earth element geochemistry characteristics of seawater and porewater from deep sea in western Pacific. Sci. Rep. 2017, 7, 16539. [CrossRef] [PubMed]

10. Pourret, O.; Tuduri, J. Continental shelves as potential resource of rare earth elements. Sci. Rep. 2017, 7, 5857. [CrossRef]

11. Glasby, G.P.; Li, J.; Sun, Z.L. Deep-sea nodules and co-rich Mn crusts. Mar. Georesour. Geotechnol. 2015, 33, 72-78. [CrossRef]

12. Josso, P.; Pelleter, E.; Pourret, O.; Fouquet, Y.; Etoubleau, J.; Cheron, S.; Bollinger, C. A new discrimination scheme for oceanic ferromanganese deposits using high field strength and rare earth elements. Ore Geol. Rev. 2017, 87, 3-15. [CrossRef]

13. Wiltshire, J.C.; Wen, X.Y.; Yao, D. Ferromanganese crusts near Johnston Island: Geochemistry, stratigraphy and economic potential. Mar. Georesour. Geotechnol. 1999, 17, 257-270.

14. Hein, J.R.; Koschinsky, A.; Halliday, A.N. Global occurrence of tellurium-rich ferromanganese crusts and a model for the enrichment of tellurium. Geochim. Cosmochim. Acta 2003, 67, 1117-1127. [CrossRef]

15. Banerjee, R. Manganese nodules as a possible source of precious metals. Curr. Sci. India 2004, 87, $278-279$.

16. Kawamoto, H. Japan's Policies to Be Adopted on Rare Metal Resources. Sci. Technol. Trends Q. Rev. 2008, 27, 57-76.

17. Bau, M.; Schmidt, K.; Koschinsky, A.; Hein, J.; Kuhn, T.; Usui, A. Discriminating between different genetic types of marine ferro-manganese crusts and nodules based on rare earth elements and yttrium. Chem. Geol. 2014, 381, 1-9. [CrossRef]

18. Jeong, K.; Kang, J.; Chough, S. Sedimentary processes and manganese nodule formation in the Korea Deep Ocean Study (KODOS) area, western part of Clarion-Clipperton fracture zones, northeast equatorial Pacific. Mar. Geol. 1994, 122, 125-150. [CrossRef]

19. KORDI. Exploration Deep-Sea Mineral Resources (Part I); KORDI: Ansan, Korea, 1996; p. 954.

20. KORDI. Cruise Report for leg KODOS 97-4; KORDI: Ansan, Korea, 1998; p. 140.

21. KORDI. Exploration for Mananese Crusts in the Southwestern Pacific; KORDI: Ansan, Korea, 1999; p. 263.

22. KORDI. Exploration for Manganese Crusts in Southwestern Pacific; KORDI: Ansan, Korea, 2001; p. 290.

23. KORDI. Exploration for Seafloor Hydrothermal Deposits and Fe-Mn Crusts in the Southwestern Pacific (Exploration Part); KORDI: Ansan, Korea, 2006; p. 378.

24. Rudnick, R.; McLennan, S.; Taylor, S. Large ion lithophile elements in rocks from high-pressure granulite facies terrains. Geochim. Cosmochim. Acta 1985, 49, 1645-1655. [CrossRef] 
25. Taylor, S. Abundance of chemical elements in the continental crust: A new table. Geochim. Cosmochim. Acta 1964, 28, 1273-1285. [CrossRef]

26. Hein, J.R.; McIntyre, B.; Koschinsky, A. The global enrichment of platinum group elements in marine ferromanganese crusts. Ext. Abstr. 2005, 10, 98-101.

27. Zhou, B.L.; Li, Z.X.; Chen, C.C. Global potential of rare earth resources and rare earth demand from clean technologies. Minerals 2017, 7, 203. [CrossRef]

28. Pak, S.-J.; Moon, J.-W.; Lee, K.-Y.; Chi, S.-B. Rare metal contents and their implications of seabed mineral resources explored by Korea. Econ. Environ. Geol. 2010, 43, 455-466.

29. Hoshino, M.; Sanematsu, K.; Watanabe, Y. REE mineralogy and resources. In Handbook on the Physics and Chemistry of Rare Earths; Elsevier: Amsterdam, The Netherlands, 2016; Volume 49, pp. 129-291.

30. Argus Metal Prices. Available online: https://www.argusmedia.com/en/metals/argus-metal-prices (accessed on 21 September 2016).

31. Friedrichs, P.; Meyer, F.M. REE database management system: Evaluation of REE deposits and occurrences. J. Sustain. Metall. 2017, 3, 13-31. [CrossRef]

32. Sterk, R.; Stein, J. Seabed mineral resources: A review of current mineral resources and future developments. Presented at the Deep Sea Mining Summit, Aberdeen, Scotland, 9-10 February 2015.

33. Hein, J.R.; Koschinsky, A.; Bau, M.; Manheim, F.T.; Kang, J.-K.; Roberts, L. Cobalt-rich ferromanganese crusts in the Pacific. In Handbook of Marine Mineral Deposits; CRC Press: Boca Raton, FL, USA, 1999; pp. $239-281$.

34. Nakamura, K.; Fujinaga, K.; Yasukawa, K.; Takaya, Y.; Ohta, J.; Machida, S.; Haraguchi, S.; Kato, Y. Rey-rich mud: A deep-sea mineral resource for rare earths and yttrium. In Handbook on the Physics and Chemistry of Rare Earths; Elsevier: Amsterdam, The Netherlands, 2015; Volume 46, pp. 79-127.

35. Sa, R.; Sun, X.; He, G.; Xu, L.; Pan, Q.; Liao, J.; Zhu, K.; Deng, X. Enrichment of rare earth elements in siliceous sediments under slow deposition: A case study of the central north Pacific. Ore Geol. Rev. 2018, 94, 12-23. [CrossRef]

36. Yasukawa, K.; Nakamura, K.; Fujinaga, K.; Machida, S.; Ohta, J.; Takaya, Y.; Kato, Y. Rare-earth, major, and trace element geochemistry of deep-sea sediments in the Indian Ocean: Implications for the potential distribution of REY-rich mud in the Indian Ocean. Geochem. J. 2015, 49, 621-635. [CrossRef]

37. Ohta, A.; Kawabe, I. REE (III) adsorption onto Mn dioxide $\left(\delta-\mathrm{MnO}_{2}\right)$ and Fe oxyhydroxide: Ce (III) oxidation by $\delta-\mathrm{MnO}_{2}$. Geochim. Cosmochim. Acta 2001, 65, 695-703. [CrossRef]

38. Wu, C.; Yuan, Z.; Bai, G. Rare earth deposits in China. Mineral. Soc. Ser. 1995, 7, 281-310. 